\title{
SEASONAL SHOREBIRD ABUNDANCE AT LAST MOUNTAIN LAKE WILDLIFE MANAGEMENT UNIT
}

MARK A. COLWELL, Department of Biology, University of North Dakota, North Dakota. 58202

The prairie wetlands of Canada, exemplified by the Last Mountain Lake Sanctuary, provide important habitats for many species of birds. Approximately $20 \%$ of shorebird species that breed in North America use prairie wetland habitat; $65 \%$ of boreal and arctic-breeding species use these wetlands during migration. ${ }^{5}$

Several aspects of shorebird biology have focused conservation efforts on understanding resource requirements of migrating birds, particularly in marine environments. ${ }^{5}$ First, migrating shorebirds typically use a limited number of staging areas that may be widely separated geographically. Second, seasonal availability of resources imposes time limits on migration resulting in concentrations of large numbers at sites with adequate food supplies. Third, many staging areas are also valuable to humans for a variety of reasons. Overall, much more is known of the abundance and habitat relationships of shorebirds in marine environments than of shorebirds that use freshwater habitats of the continental interior. ${ }^{1} 3 \quad 56$

\section{Study area and methods}

Data on shorebird abundance were collected during 1984, a year of extreme drought when approximately $90 \%$ of local wetlands were dry. Three sites at Last Mountain Lake Wildlife Management Unit were censused that differed in substrate, vegetation and open-water features. Censuses during 1983 indicated that these sites were representative of habitats that were used by nearly all breeding and migrating shorebirds in the area.

Shorebirds were observed from 30 April to 30 August at Lanigan Creek (S4-29-23-W2; $\left.51^{\circ} 27^{\prime} \mathrm{N} 105^{\circ} 11^{\prime} \mathrm{W}\right)$, a 100 ha site composed of flooded meadow with Wild Barley (Hordeum jubatum), Seaside Arrowgrass (Triglochin maritima), sedges (Carex spp.) and rushes Uuncus spp.), and prairie with blue grasses (Poa spp.), Salt Grass (Distichlis stricta), wheatgrasses (Agropyron spp.), Western Snowberry (Symphoricarpos occidentalis) and Prickly Rose (Rosa acicularis) that bordered a permanent water source. During spring flooded meadow was extensive and mudflats constituted a small portion of available habitat. As summer progressed the meadow dried and mudflats became increasingly available.

Shorebirds were censused from 8 May to 28 August at a 10 ha site located on Basin A (S33-28-23-W2; 510 26'N 105 $\left.11^{\prime} \mathrm{W}\right)$. Shallow-water areas and adjoining mudflats under varying moisture conditions typified Basin A habitat. Bulrush stands (Scirpus spp.) dotted open-water habitat in spring; a dense growth of Red Samphire (Salicornia rubra) covered mudflats as water levels dropped. Otherwise the study area was unvegetated.

Shorebirds also were censused from 3 May to 20 August at Perry's Beach (W30-27-23-W2; $51^{\circ} 18^{\prime} \mathrm{N} 105^{\circ} 12^{\prime} \mathrm{W}$ ), a $1.5 \mathrm{~km}$ stretch of sandy and rocky beach on the east shore of Last Mountain Lake. The beach varied in width from $5-30 \mathrm{~m}$ and was largely unvegetated. Lake water 
levels changed very little during the study.

At Lanigan Creek and Basin A one to three observers censused shorebirds from 3-m towers using 20-25x spotting scopes and $7 x$ binoculars. At Perry's Beach one observer walked the beach and recorded data from vantage points. Censuses at Lanigan Creek were conducted at random time intervals; each Basin A census was paired with a Lanigan Creek survey. Censuses at Perry's Beach were conducted at predetermined times.

The late April to August sampling period was divided into spring (April-june) and summer (July-August) based on the chronology of migration and breeding at Last Mountain Lake. ${ }^{2}$ Total numbers of censuses at each site were as follows: Basin A spring 30, summer 23, Lanigan Creek spring 123, summer 99, Perry Beach spring 3, summer 19.

\section{Results}

Twenty-nine species of shorebirds were recorded during 1984 (includes two species of dowitchers not distinguished in Table 1). One other species, Buff-breasted Sandpiper also was observed during the study; it occurred on one occasion near the Perry's Beach study site during August. The total number of species recorded (regardless of season) was 25 at Basin A and 23 at each of Lanigan Creek and Perry's Beach. During any one season, however, the number of species ranged from 10 at Perry's Beach (spring) to 24 at Basin A (spring).

There was considerable variability in the seasonal abundance of species. The most abundant shorebirds during spring at Basin A were Stilt Sandpiper, Wilson's Phalarope and Semipalmated Sandpiper; the most common summer species were Semipalmated Sandpiper, dowitchers and Lesser Yellowlegs. Overall, $80 \%$ of species at Basin A were recorded during both spring and summer.

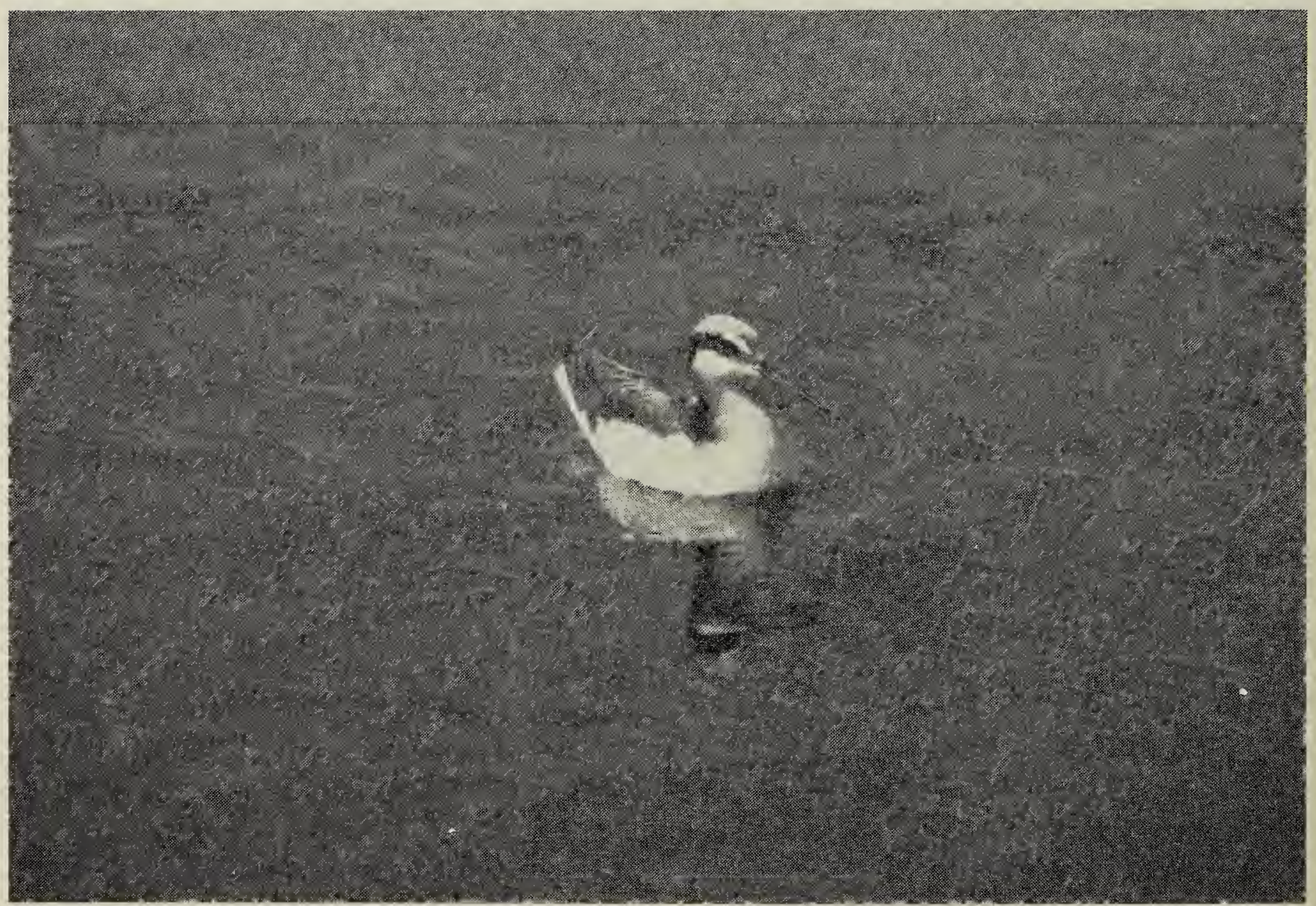




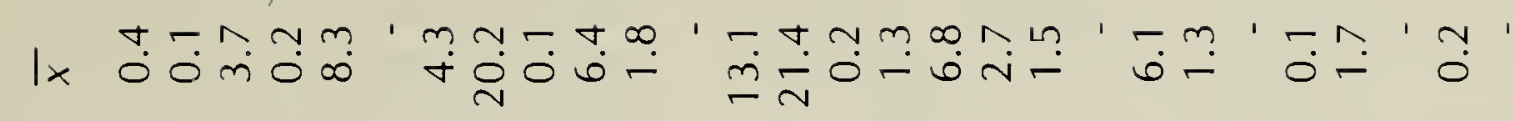

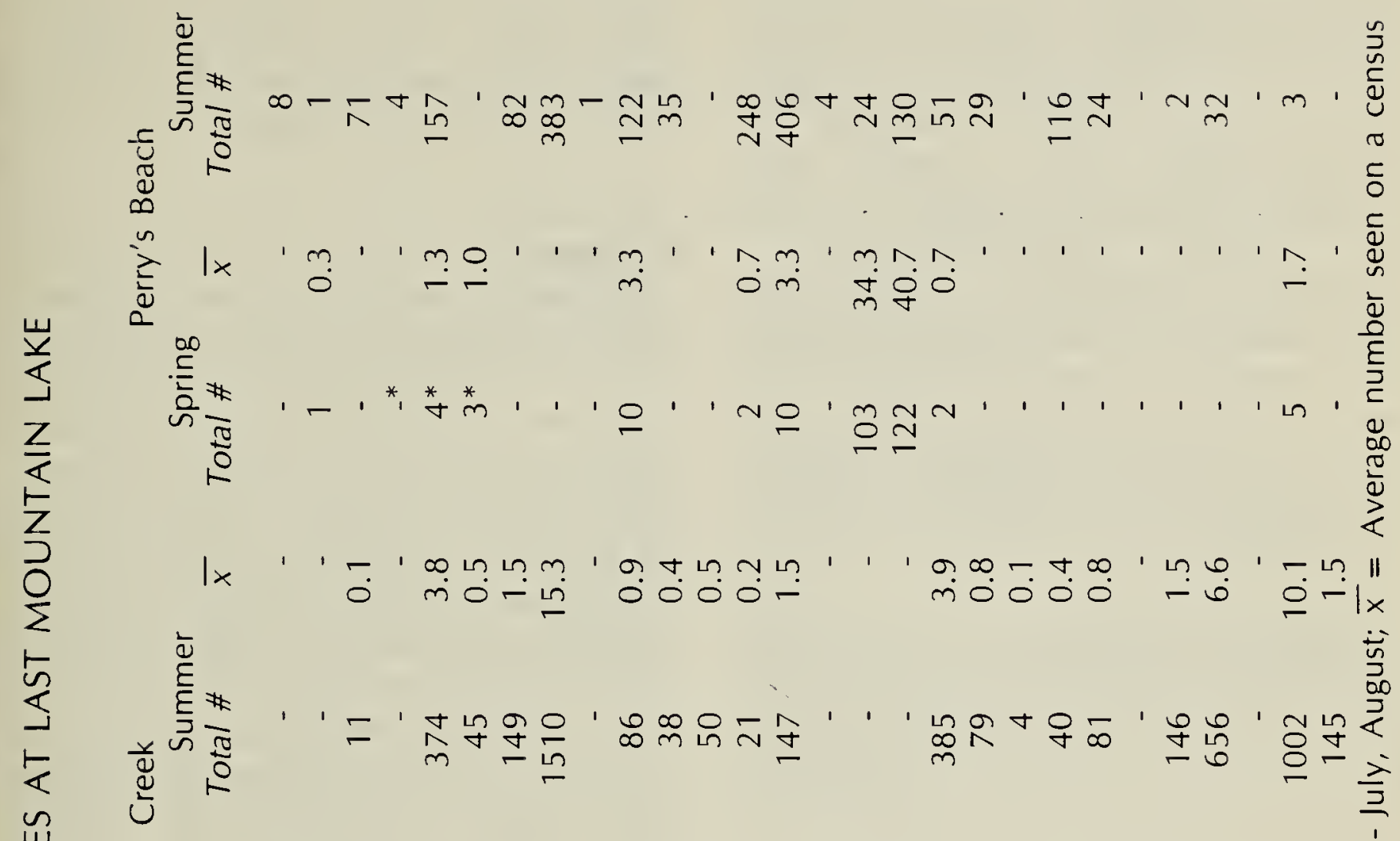

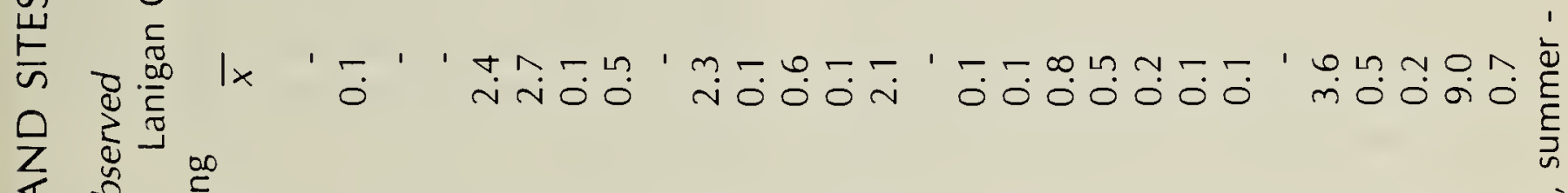

U U U

吉 $\quad$ r

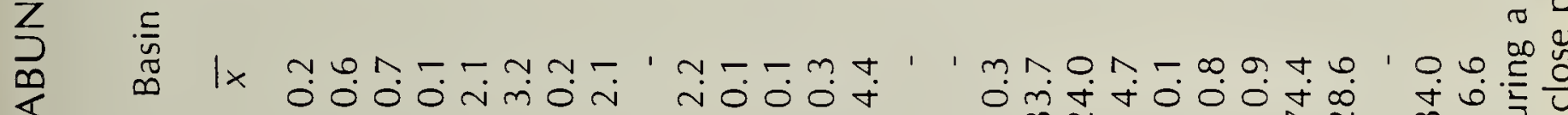

0 产 败

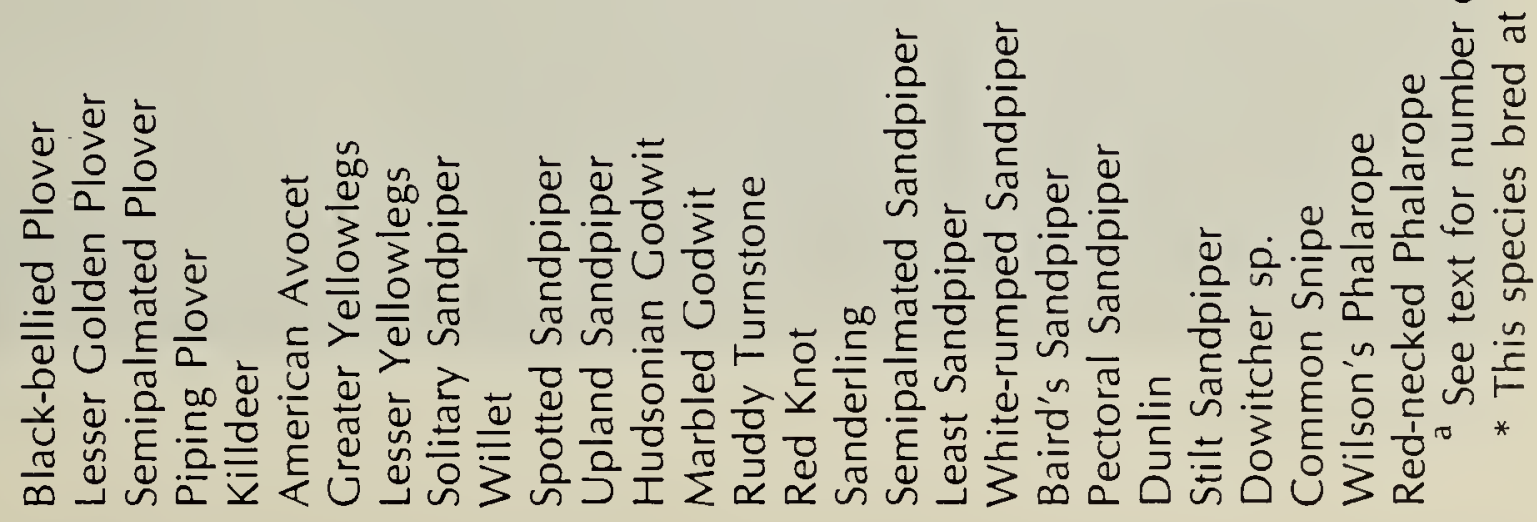

45(4). December 1987 
Shorebird numbers at Lanigan Creek were much lower than at Basin A, despite the larger study area. The most common spring shorebirds were Wilson's Phalarope and Stilt Sandpiper; the most common summer species were Lesser Yellowlegs and Wilson's Phalarope. At Lanigan Creek $78 \%$ of species were observed during both seasons.

The spring shorebird assemblage at Perry's Beach was dominated by Red Knot and Sanderling. Lesser Yellowlegs, Hudsonian Godwit and Marbled Godwit were most abundant during summer. Overall $39 \%$ of species were present during spring and summer.

Shorebird abundance was not compared between sites owing to differences in the size and habitat configurations of the study areas. However, sites differed in species composition. During spring, Basin A shared $77 \%$ of the species with Lanigan Creek and only 38\% with Perry's Beach. Lanigan Creek shared $45 \%$ of species with
Perry's Beach. Species assemblages at the three sites were more similar during summer than spring. During summer Basin A had $82 \%$ and $72 \%$ of species in common with Lanigan Creek and Perry's Beach, respectively; Lanigan Creek and Perry's Beach shared $58 \%$ of species.

\section{Discussion}

Differences among sites in the abundance of shorebirds may be related to habitat features that reflect food or other resources. The presence of Semipalmated Plover at Basin A and its absence a short distance away at Lanigan Creek indicates that the availability of extensive mudflats may be an important habitat feature for this species. Similarly the nearly exclusive use of sandy and rocky lakeshore habitat by Red Knot and Sanderling suggests that these species have relatively strict habitat preferences. In contrast, species such as Lesser Yellowlegs, Marbled Godwit and some of the small peeps were found at all three sites.

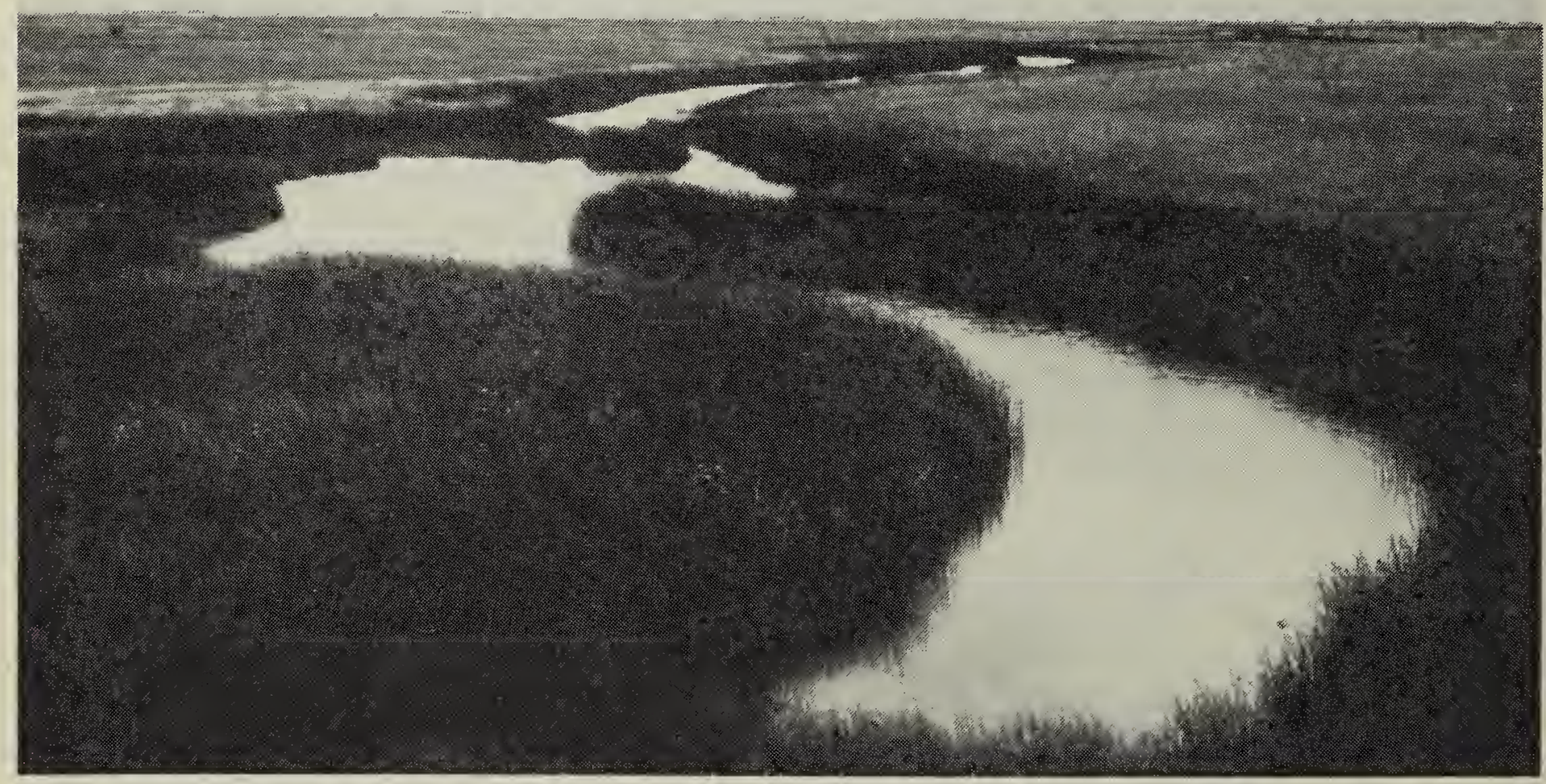

Lanigan Creek

P.S. Taylor 
Apparent differences in shorebird assemblages may stem from the fact that fewer censuses were conducted at Perry's Beach, particularly during the spring. However species such as Red Knot, Sanderling and Ruddy Turnstone were largely responsible for the differences in species composition. These species were regularly observed at other lakeshore sites that were characterized by rocky and sandy beaches; they were rarely observed at Basin A and Lanigan Creek, despite extensive coverage of these sites.

Limited habitat availability stemming from drought conditions may have resulted in unusual patterns of habitat use during this study. In addition, shorebirds may have concentrated in larger numbers than usual at a limited number of sites. From a management perspective, however, drought conditions provide a situation offering special insights into habitat requirements of species. At such times limited habitat may force individuals to concentrate in areas where they may be subject to reduced food abundance, increased interference while foraging, and elevated risks of disease. ${ }^{4}$

In summary, Last Mountain Lake Wildlife Management Unit offers a diversity of habitats for more than 20 species of migrating shorebirds and 9 locally breeding species.

\section{Acknowledgements}

I thank T. Colwell, R. (Ell) Harvey, S. Gin and 1. Gollop for field assistance. Logistical support was provided by C. Jorgenson, P.S. Taylor and the Canadian Wildlife Service. Research was funded by the C.W.S. and NSF Grants PCM-8315758 and DCB-8608162 to L. Oring and A. Fivizzani.

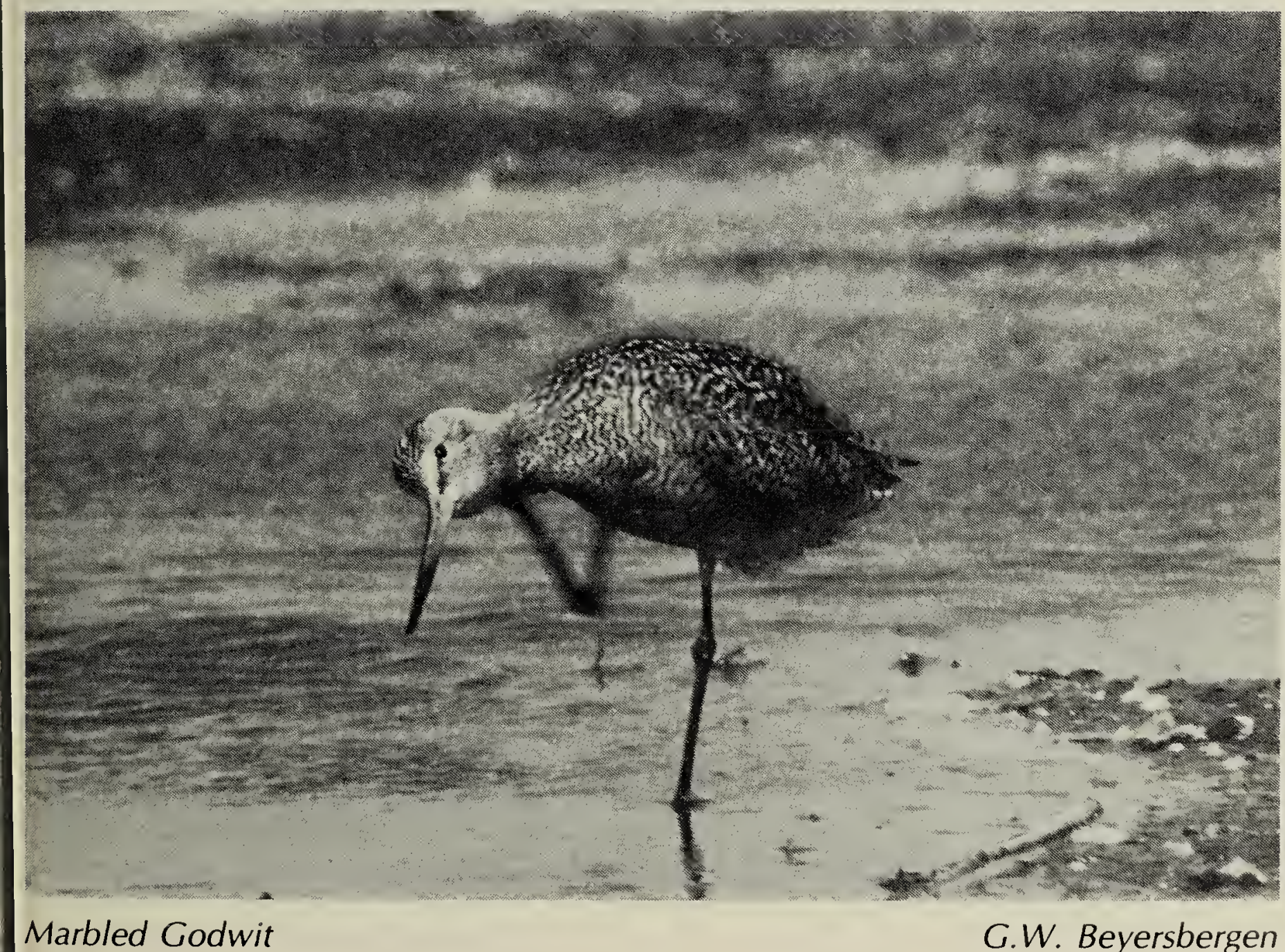

Marbled Godwit

G.W. Beyersbergen 
1 BURGER, J. 1984. Abiotic factors affecting migrant shorebirds. Pp 1-72 IN BURGER, J. and B.L. OLLA, Eds. Shorebirds. Migration and foraging behavior. Vol. 6. Plenum Press, N.Y.

2 COLWELL, M.A., F.D., FELLOWS and L.W. ORING In Press, Chronology of Shorebird Migration at Last Mountain Lake, National Wildlife Area, Saskatchewan, Canada. Wader Study Group Bulletin.

3 EVANS, R., J.D. GOSS-CUSTARD and W.G. HALE 1984. Coastal waders and wildfowl in winter. Cambridge Univ. Press, Cambridge. $242 \mathrm{pp}$.

4 GOSS-CUSTARD, J.D. 1980. Competition for food and interference among waders. Ardea 68:31-52.
5 MYERS, I.P., R.I.G. MORRISON, P.Z. ANTAS, B.A. HARRINGTON, T.E. LOVEJOY, M. SALLABERRY, S.E. SENNER and A. TARAK 1987. Conservation strategy for migratory species. Amer. Scient. 75:19-26.

6 PITELKA, F.A. 1979. Shorebirds in marine environments. Studies in avian biology. No. 2. Allen Press, Lawrence, Kansas. 223 pp.

NOTE: Mark Colwell's studies at Last Mountain Lake were focused on the Wilson's Phalarope. Since this paper was developed from the data collected at three discrete sites in only one season the large concentrations of shorebirds that do occur at the lake were not reported here. As an example, there have been reports of 15 thousand Red-necked Phalaropes, 6 thousand Sanderlings and 5 thousand Ruddy Turnstones.

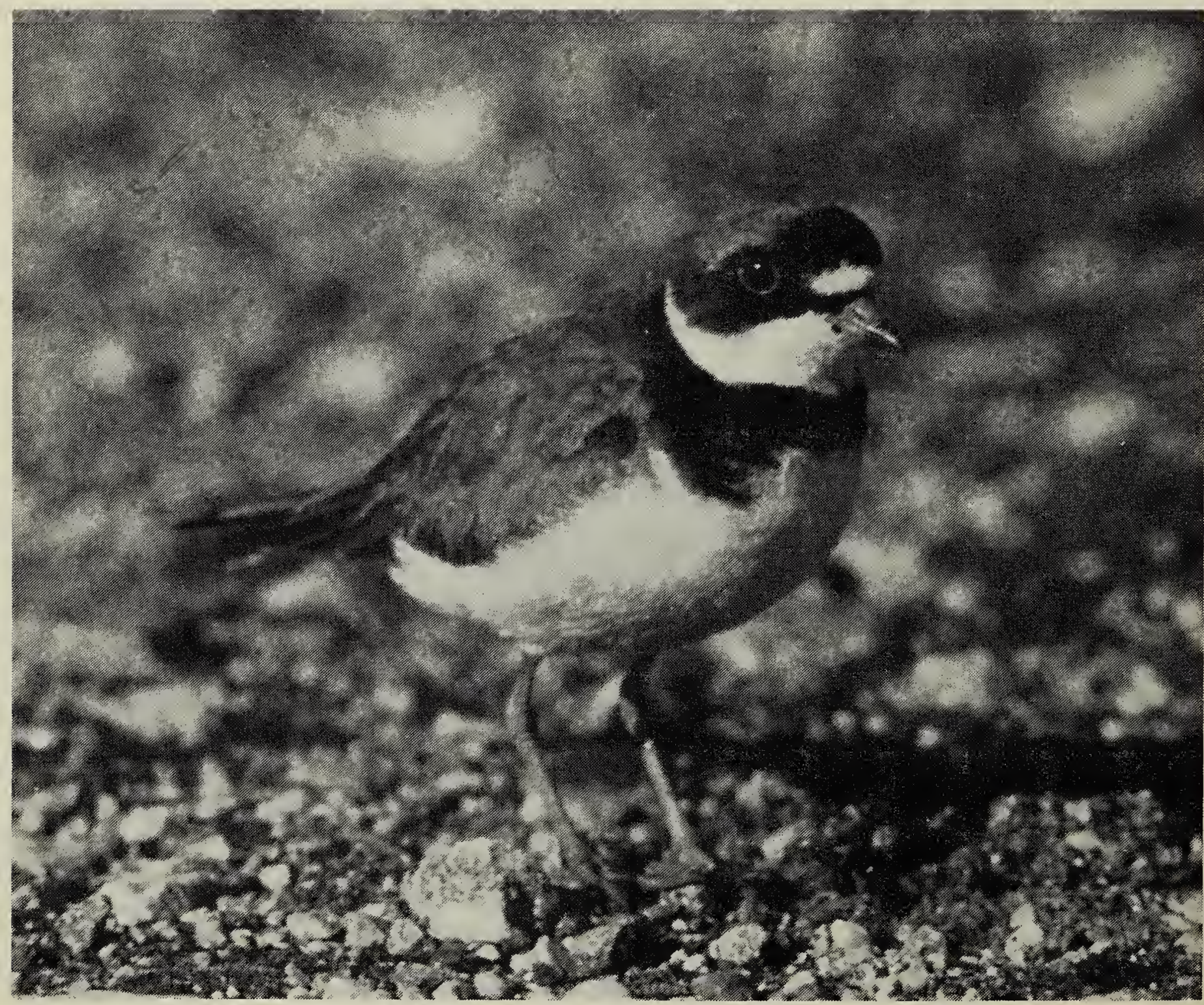

